\title{
ANALISIS PENGGUNAAN MEDIA GAMBAR BERSERI UNTUK MENINGKATKAN KEMAMPUAN MEMBACA SISWA DISLEKSIA DI SEKOLAH DASAR
}

\author{
Arif Widodo, Dyah Indraswati, Agam Royana \\ Pendidikan Guru Sekolah Dasar FKIP Universitas Mataram \\ Pendidikan Agama Islam FTK UIN Mataram \\ arifwidodo@unram.ac.id
}

\begin{abstract}
Abstrak
Anak berkebutuhan khusus memerlukan layanan belajar yang berbeda dengan anak pada umumnya. Salah satu jenis anak berkebutuhan khusus adalah anak yang mengalami kesulitan belajar tipe disleksia. Pada umumnya anak disleksia mengalami beberapa kesulitan belajar salah satunya adalah kesulitan membaca. Penelitian ini bertujuan untuk menganalisis penggunaan gambar berseri sebagai media membaca anak disleksia. Subjek dalam penelitian ini adalah siswa disleksia kelas IV di SDN Repok Puyung. Metode yang digunakan dalam penelitian ini adalah deskriptif kualitatif. Pengumpulan data dilakukan melalui tes membaca dan observasi. Data disajikan dalam bentuk diagram kemudian dianalisis secara deskriptif. Masalah utama dalam penelitian ini adalah apakah media gambar berseri dapat membantu anak disleksia dalam meningkatkan kemampuan membaca. Hasil penelitian menunjukkan bahwa penggunaan media gambar berseri dapat meningkatkan kemampuan membaca. Peningkatan kemampuan membaca sebagai reaksi atas membaiknya daya ingat anak disleksia melalui gambar.Temuan lain dalam penelitian ini aktivitas belajar dan motivasi membaca siswa disleksia mengalami peningkatan.
\end{abstract}

Kata Kunci: gambar berseri, kemampuan membaca, siswa disleksia, sekolah dasar

\section{Abstract}

Children with special needs require different learning services with children in general. One kind of children with special needs is a child who has difficulty in learning and it is called dyslexia. Generally, children with dyslexia have some difficulties in learning and one of it is difficulty reading. The study aims to analyze the use of radiant images as media in reading for Dyslexia children. The subject in this study is Dyslexia students grade IV at SDN Repok Puyung. The methods used in this study is qualitative descriptive. Data collection was conducted through reading and observation tests. Data presented in the form of diagrams, then analyzed descriptively. The main problem in this research is whether the serial image media can help Dyslexia students in improving their reading skill. The results showed that the use of serial image media could improve their reading skill. The increasing of reading skills as reaction for memory improvement of Dyslexia student through pictures. Other findings in this study are improvement in learning activity and reading motivation for Dyslexia students.

Keywords: serial image, reading skills, dyslexia students, elementary school 


\section{A. PENDAhULUAN}

Anak berkebutuhan khusus telah mendapat tempat tersendiri dengan diselenggarakannya pendidikan inklusif. Berdasarkan Peraturan Menteri No 70 tahun 2009 dalam penyelenggaraan pendidikan inklusif anak berkebutuhan khusus harus mendapatkan layanan pendidikan yang sesuai dengan kebutuhan dan hak asasinya. ${ }^{1}$ Namun demikian tidak jarang sekolah yang mengaku menyelenggarakan pendidikan inklusif tetapi masih diskriminatif terhadap anak berkebutuhan khusus. Terdapat sebuah penelitian yang menyatakan bahwa masih ada sekolah inklusi yang melakukan pembatasan terhadap siswa yang diterima di sekolah. ${ }^{2}$ Hal ini tentunya bertolak belakang dengan amanah dalam perundang-undangan yang menyatakan bahwa semua anak berkebutuhan khusus harus mendapat layanan pendidikan. Persamaan hak asasi dalam bidang pendidikan harus mendapat perhatian semua pihak. Diskriminasi terhadap anak berkebutuhan khusus merupakan pelanggaran terhadap hak asasi dalam bidang pendidikan. Allah SWT telah berfirman tentang pentingnya persamaan derajat dan menghargai keragaman di antara manusia.

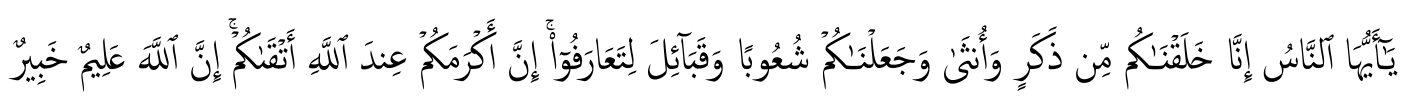

"Hai manusia, sesungguhnya Kami menciptakan kamu dari seorang laki-laki dan seorang perempuan dan menjadikan kamu berbangsa-bangsa dan bersuku-suku supaya kamu saling kenal-mengenal. Sesungguhnya orang yang paling mulia di antara kamu di sisi Allah ialah orang yang paling takwa di antara kamu. Sesungguhnya Allah Maha Mengetahui lagi Maha Mengenal.”(QS. Al-Hujuraat; 13)

Melalui ayat di atas telah terlihat jelas bahwa kemuliaan manusia hanya ditentukan oleh aspek ketakwaan yang melekat pada dirinya, bukan dinilai dari kesempurnaan fisik atau aspek material yang dikenal masyarakat pada umumnya. Hanya Allah SWT yang memiliki otoritas dalam menilai kemuliaan manusia. Hal ini tercermin dalam penutup ayat yang menerangkan bahwa Allah Maha Mengetahui lagi Maha Mengenal. Meskipun demikian esensi takwa pada hakikatnya dapat tersirat

\footnotetext{
${ }^{1}$ Peraturan Menteri Pendidikan Nasional (Permendiknas) Nomor 70 Tahun 2009 Tentang Pendidikan Inklusif Bagi Peserta Didik Yang Memiliki Kelainan Dan Memiliki Potensi Kecerdasan Dan/ Atau Bakat Istimewa (Republik Indonesia, 2009) <https: // kelembagaan.ristekdikti.go.id/ wp-content/ uploads/ 2016/ 11/ Permen-No.-70-2009-tentang-pendidiian-inklusif-memiliki-kelainan-kecerdasan.pdf

2 Sulthon Sulthon, Pendidikan Dasar Inklusif Di Kabupaten Pati: Harapan Dan Kenyataan, INKLUSI, 6.1 (2019), $151<$ https://doi.org/10.14421/ijds.060107>
} 
melalui bagaimana seseorang berbuat baik pada sesamanya. Maka dari itu setiap orang hendaknya dapat saling menghormati kelebihan dan kekurangan orang lain. Termasuk dalam hal ini anak berkebutuhan khusus harus dihormati dan dihargai haknya berdasarkan Undang-Undang yang berlaku. Allah SWT memerintahkan agar manusia selalu berbuat baik tanpa memandang perbedaan derajat, kedudukan maupun berbagai label yang dianggap sebagai sebuah kekurangan lainnya. Maka dari itu diskriminasi terhadap anak berkebutuhan khusus hendaknya segera dihilangkan. Anak berkebutuhan khusus dengan segala jenis kebutuhannya merupakan bentuk keragaman yang diciptakan Tuhan. Hal ini dikarenakan perbedaan adalah kehendak Allah SWT seperti yang terdapat dalam firman pada surat al-Maidah ayat 48:

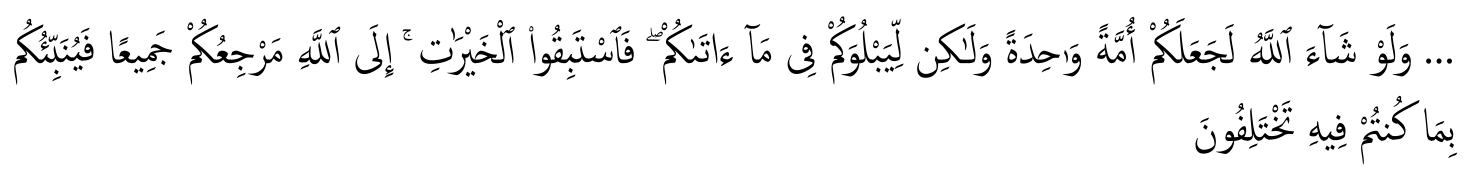

....Sekiranya Allah menghendaki, niscaya kamu dijadikan-Nya satu umat (saja), tetapi Allah hendak menguji kamu terhadap pemberian-Nya kepadamu, maka berlomba-lombalah berbuat kebajikan. Hanya kepada Allah-lah kembali kamu semuanya, lalu diberitahukan-Nya kepadamu apa yang telah kamu perselisihkan itu. (almaidah : 48)

Perbedaan dan keragaman berdasarkan ayat di atas merupakan kehendak Allah SWT. Melalui ayat tersebut manusia diwajibkan belajar tentang arti perbedaan. Setiap manusia memiliki potensi dan bakat masing-masing, tidak terkecuali dengan anak berkebutuhan khusus. ${ }^{3}$ Maka dari itu manusia tidak boleh menganggap remeh orang lain, karena keragaman yang menciptakan adalah Allah SWT. Jika Allah SWT berkehendak bisa saja semua orang dibuat sama, akan tetapi Allah tidak menghendaki demikian agar manusia dapat mengambil pelajaran dari perbedaan itu. Termasuk dalam hal ini manusia dapat belajar dari anak-anak berkebutuhan khusus. Minimal sebagai manusia yang merasa normal seharusnya selalu mengucap syukur jika dibandingkan dengan anak berkebutuhan khusus yang memiliki berbagai kekurangan. Maka dari itu melalui penyelenggaraan pendidikan inklusif diharapkan peserta didik terbiasa menghadapi perbedaan, sehingga karakter toleransi dapat tumbuh dengan

${ }^{3}$ Arif Widodo, Dyah Indraswati, Deni Sutisna, and others, identifikasi Bakat Peserta Didik Berkebutuhan Khusus (PDBK) Di Madrasah Inklusi Kabupaten Lombok, JPI (Jurnal Pendidikan Inklusi), 3.2 (2020), 102 $<$ https://doi.org/10.26740/inklusi.v3n2.p102-116> 
sendirinya. Melalui pengembangan sikap toleransi perserta didik dilatih untuk hidup berdampingan dalam perbedaan. ${ }^{4}$ Tujuannya adalah terjadi harmoni dan keselarasan dalam berbagai lingkungan kehidupan. ${ }^{5}$

Salah satu lembaga pendidikan yang telah menyelenggarakan pendidikan inklusif dengan baik adalah SDN Repok Puyung. Sekolah ini terletak di salah satu kecamatan di kabupaten Lombok Tengah. Terdapat beberapa anak berkebutuhan khusus yang sedang belajar di sekolah ini. Mulai dari anak yang mengalami gangguan perilaku hingga yang mengalami hambatan akademik. Proses identifikasi anak berkebutuhan khusus di sekolah ini sudah berjalan dengan baik. Proses identifikasi penting dilakukan untuk mengenal dan mendapatkan pelayanan yang tepat bagi anak berkebutuhan khusus. ${ }^{6}$ Siswa yang mengalami hambatan perilaku terdiri dari hiperaktif dan tuna laras. Berdasarkan sebuah penelitian dapat diketahui bahwa dalam pembentukan perilaku sosial berkaitan erat dengan pola asuh dan kelekatan orang tua. ${ }^{7}$ Hal ini dapat dipahami bahwa kondisi masyarakat di sekitar SDN Repok Puyung banyak yang berprofesi sebagai TKW. Selain terdapat siswa yang mengalami gangguan perilaku sosial di sekolah ini juga ditemukan siswa yang mengalami hambatan akademik, salah satunya yang jumlahnya cukup banyak adalah penderita disleksia.

Disleksia merupakan salah satu jenis kesulitan belajar ditandai dengan ketidakmampuan anak dalam membaca dan menulis. ${ }^{8}$ Penderita disleksia tidak hanya kesulitan membaca tetapi juga sulit mengurutkan kata demi kata baik dari atas ke bawah maupun dari kiri ke kanan. Anak disleksia memiliki masalah dalam fonologi yang berkaitan dengan aspek sistematik pada huruf dan bunyi. Selain itu anak disleksia juga mengalami masalah dalam mengingat perkataan, menyusun sesuatu secara

${ }^{4}$ Miftachul A'la, Penguatan Karakter Toleransi Melalui Permainan Tradisional Dalam Pembelajaran PJOK di Sekolah Dasar, MAGISTRA: Media Pengembangan Ilmu Pendidikan Dasar Dan KeIslaman, 2019, hlm.130-45

${ }^{5}$ Arif Widodo, Sa'dun Akbar, and Sujito Sujito, Analisis Nilai-Nilai Falsafah Jawa Dalam Buku Pitutur Luhur Budaya Jawa Karya Gunawan Sumodiningrat Sebagai Sumber Belajar Pada Pembelajaran IPS, Jurnal Penelitian Dan Pendidikan IPS (JPPI), 11.2 (2017), 152-79<http:// ejournal.unikama.ac.id/index.php/ JPPI/ article/ download/1887/ 1489/>

${ }^{6}$ Eileen Slater, The Identification of Gifted Children in Australia: The Importance of Policy, TalentEd, 30.1 (2018), $1<$ https://www.researchgate.net/profile/Eileen_Slater/publication/322419883>.

7 Arif Widodo, Penyimpangan Perilaku Sosial Ditinjau Dari Teori Kelekatan Bowlby (Studi Kasus Terhadap Anak Tenaga Kerja Wanita Di Lombok Barat), Entita: Jurnal Pendidikan Ilmu Pengetahuan Sosial dan Ilmu-Ilmu Sosial, 2020, hlm. 83-98

${ }^{8}$ Nurul Hidayati Rofiah, Proses Identifikasi: Mengenal Anak Kesulitan Belajar Tipe Disleksia Bagi Guru Sekolah Dasar Inklusi, INKLUSI, 2.1 (2015), $109<$ https://doi.org/10.14421/ijds.020110> 
sistematis, daya ingat yang pendek serta bermasalah pada sistem tata bahasa. Kegiatan membaca melibatkan beberapa aspek kemampuan yaitu kemampuan dalam mengenali kata, kemampuan dalam memahami bunyi fonem, dan kemampuan dalam menghubungkan antara bunyi dan huruf. ${ }^{9}$

Ketiga kemampuan inilah yang bermasalah pada anak disleksia. Kunci utama penyebab anak disleksia adalah permasalahan di dalam otak, maka dari itu penyembuhan terhadap anak disleksia salah satu alternatifnya adalah dengan melakukan stimulus pada bagian otak terutama untuk pembelajaran mengeja dan membaca. Hal ini dikarenakan anak disleksia mengalami kesulitan membaca meskipun memiliki IQ yang sama dengan anak yang normal. ${ }^{10}$ Melalui layanan dan bimbingan belajar yang beragam dan teratur bukan tidak mungkin anak disleksia dapat mencapai kemajuan.

Anak disleksia juga sulit menerima perintah sehingga sering dianggap mengalami gangguan konsentrasi. Hal ini dikarenakan tidak sedikit anak disleksia yang mengalami komplikasi, dalam hal ini dapat dikategorikan sebagai tuna ganda. Dapat dikatakan tuna ganda apabila terdapat lebih dari satu gangguan yang ada pada diri anak. Anak yang mengalami disleksia bisa juga disebabkan karena adanya gangguan psikologis yang menyebabkan terganggunya konsenstrasi seperti halnya yang terjadi pada anak hiperaktif. Implikasinya adalah selain anak mengalami gangguan perilaku juga mengalami kesulitan belajar.

Keberadaan siswa dengan kesulitan belajar tipe disleksia seringkali tidak disadari oleh guru. Akibatnya adalah siswa tersebut dipaksa untuk mengikuti kegiatan pembelajaran sesuai dengan standart KKM yang berlaku untuk semua siswa pada umumnya. Konsekuensi yang harus diterima anak disleksia dengan adanya penyamarataan tersebut seringkali mereka dilabeli dengan anak bodoh. Kondisi semacam ini jika dibiarkan berlarut tidak akan membantu anak yang mengalami kebutuhan khusus keluar dari masalahnya. Siswa disleksia jika diberikan intervensi yang tepat sejak dini akan menghasilkan sesuatu yang luar biasa, namun jika penanganannya terlambat maka akan berdampak pada gangguan sosial dan emosional.

\footnotetext{
${ }^{9}$ Endang Widyorini and Julia Maria van Tiel, Disleksia: Deteksi, Diagnosis, Penanganan Di Sekolah Dan Di Rumah, 1st edn, Jakarta: Prenadamedia Group, 2017, hlm. 90-93.

${ }^{10}$ Sheila Devaraj and Samsilah Roslan, Apa Itu Disleksia?: Panduan Untuk Ibu Bapa Guru \& Kaunselor, PTS Profesional, 2006, hlm. 4-5.
} 
Terlebih lagi dengan adanya label anak bodoh membuat seorang siswa menjadi semakin tertekan, stress dan akhirnya berdampak pada perubahan tingkah lakunya.

Penderita disleksia sebagai salah satu jenis anak berkebutuhan khusus harus mendapatkan layanan belajar khusus yang berbeda dengan siswa pada umumnya. ${ }^{11}$ Memasukkan anak disleksia ke dalam sekolah inklusif adalah langkah yang tepat. Hal ini sesuai dengan hasil sebuah penelitian yang menyatakan pentingnya pemisahan layanan belajar bagi anak disleksia. ${ }^{12}$ Seiring dengan telah ditetapkannya peraturan tentang pendidikan inklusif, layanan belajar bagi anak berkebutuhan khusus semakin digalakkan. Pada umumnya anak disleksia mengalami kesulitan belajar yang kompleks, salah satunya adalah kesulitan membaca. Kemampuan membaca merupakan kemampuan dasar yang sangat penting untuk dikuasai siswa. Jika aktivitas membaca rendah dapat dipastikan prestasi belajarnya rendah. ${ }^{13}$ Hal ini tidaklah berlebihan mengingat unsur yang paling utama dalam pendidikan adalah kegiatan membaca. Terganggunya aktivitas membaca dapat dipastikan tujuan pendidikan secara umum tidak akan tercapai. Terlebih lagi dalam menghadapi tantangan abad 21 kegiatan literasi harus diutamakan. ${ }^{14}$ Maka dari itu kesulitan membaca yang dialami oleh siswa disleksia hendaknya segera dicari solusinya.

Salah satu bentuk layanan belajar bagi anak berkebutuhan khusus adalah pemberian treatment agar kesulitan dan hambatan belajar yang dialami siswa berkebutuhan khusus dapat diatasi. Harapannya adalah melalui layanan belajar yang tepat siswa yang berkebutuhan khusus dapat mengembangkan secara optimal potensi yang ada pada dirinya. ${ }^{15}$ Terdapat berbagai macam treatment yang dapat dilakukan untuk mengatasi kesulitan belajar pada anak disleksia, salah satunya adalah dengan penggunaan media sebagai alat bantu belajar. Peranan media sangat penting dalam

${ }^{11}$ Rohaty Mohd Majzub and Shafie Mohd Nor, Simptom Disleksia Kanak-Kanak Prasekolah, Jurnal Pendidikan Malaysia, 2005, hlm. 3-19

12 Anggun Dyah Anjarsari, Penyelenggaraan Pendidikan Inklusi Pada Jenjang SD, SMP, Dan SMA Di Kabupaten Sidoarjo, JPI (Jurnal Pendidikan Inklusi), 1.2 (2018), $91<$ https://doi.org/10.26740/inklusi.v1n2.p91104>

13 Arif Widodo, Husniati Husniati, and others, Prestasi Belajar Mahasiswa PGSD Pada Mata Kuliah Pengantar Pendidikan Ditinjau Dari Segi Minat Baca, Jurnal Bidang Pendidikan Dasar, 4.1 (2020), 26-36 $<$ https://doi.org/https://doi.org/10.21067/jbpd.v4i1.3808>

${ }^{14}$ Arif Widodo, Dyah Indraswati, and Muhammad Sobri, Analisis Nilai-Nilai Kecakapan Abad 21 Dalam Buku Siswa SD/MI Kelas V Sub Tema 1 Manusia Dan Lingkungan, Tarbiyah: Jurnal Ilmiah Kependidikan, 8.2 (2019), $125<$ https://doi.org/10.18592/tarbiyah.v8i2.3231>

${ }^{15}$ Arif Widodo, Linda Feni Haryati, and others, Proses Identifikasi Peserta Didik Berkebutuhan Khusus Di MI NW Tanak Beak Kabupaten Lombok Barat, Progres Pendidikan, 1.2 (2020), 63-71 $<$ http://prospek.unram.ac.id/index.php/PROSPEK/article/view/10/11> 
pembelajaran mengingat media dapat bermanfaat untuk membantu menyampaikan informasi dari pembelajar kepada subjek ajar secara efektif. Terlebih lagi dengan diterapkannya kurikulum 2013 pembelajaran lebih ditekankan padat metode dan media. Pembelajaran konvensional yang identik dengan metode ceramah mulai ditinggalkan. Hal ini sesuai dengan pernyataan yang menyatakan bahwa di era globalisasi dan informasi penggunaan media pembelajaran tidak hanya sekedar tuntutan tetapi juga merupakan sebuah kebutuhan ${ }^{16}$ Pembelajaran di era ini hendaknya mengedepankan metode pembelajaran yang mengarah pada keterampilan abad 21 .

Penggunaan media dalam pembelajaran disesuaikan dengan situasi dan kondisi masing-masing lingkungan belajar. Aspek yang tidak kalah penting sebagai bahan pertimbangan pemilihan media pembelajaran adalah usia subjek belajar, dalam hal ini adalah siswa. Media pembelajaran yang sesuai dengan karakteristik anak sekolah dasar adalah media gambar. Hal ini harus disesuaikan dengan kondisi psikologis siswa Sekolah Dasar yang pada umumnya menyukai dengan hal-hal yang konkrit. Penggunaan media pembelajaran bagi anak berkebutuhan khusus jenjang pendidikan dasar belum berjalan optimal. Menurut sebuah penelitian yang dilakukan pada salah satu madrasah di Lombok Barat kurang optimalnya penggunaan media pembelajaran karena tidak banyak guru yang pernah mengikuti pelatihan dalam menangani anak berkebutuhan khusus. ${ }^{17}$ Maka dari itu perlu dilakukan kajian terhadap penggunaan media pembelajaran bagi anak berkebutuhan khusus di Sekolah Dasar, terutama bagi anak yang mengalami masalah disleksia.

Terdapat banyak penelitian terdahulu yang mengkaji tentang anak disleksia. Salah satunya adalah penelitian yang mengkaji penggunaan stimulasi visual dalam meningkatkan kemampuan membaca penderita disleksia. ${ }^{18}$ Penelitian tersebut menghasilkan simpulan bahwa terdapat perbedaan kemampuan membaca sebelum dan sesudah stimulasi visual. Hal ini dikarenakan media visual dapat bermanfaat dalam memperlancar pemahaman serta memperkuat ingatan. Selain itu melalui media visual, minat belajar menjadi meningkat dan dapat menghubungkan secara nyata antara materi

\footnotetext{
${ }^{16}$ Purwanata Lalu Satya and Rianto Edy, Penerapan Media Video Berbasis IT Terhadap Kemampuan Membaca Kalimat Sederhana Anak Tunagrahita Ringan Kelas III, Pendidikan Khusus, 2016, 1-10 $<$ https://jurnalmahasiswa.unesa.ac.id/index.php/jurnal-pendidikan-khusus/article/view/30061/27561>

${ }^{17}$ Linda Feni Haryati and others, Optimalisasi Penggunaan Media Pada Anak Berkebutuhan Khusus Di MI NW Tanak Beak Narmada, Progres Pendidikan, 2020, hlm. 88-97

${ }^{18}$ Fajar Kawuryan and Trubus Raharjo, Pengaruh Stimulasi Visual Untuk Meningkatkan Kemampuan Membaca Pada Anak Disleksia, 10 Jurnal Psikologi Pitutur, 2012, hlm. 9-20.
} 
pelajaran dengan kehidupan nyata sehingga pembelajaran lebih kontekstual. Penelitian selanjutnya mengkaji tentang penggunaan animasi dalam pembelajaran anak disleksia. Penelitian tersebut menunjukkan adanya manfaat penggunaan animasi terhadap hasil belajar anak disleksia. ${ }^{19}$ Penelitian selanjutnya menguji tentang adakah pengaruh penggunaan permainan scrabble dalam meningkatan kemampuan membaca anak disleksia. Melalui penelitian tersebut dapat diketahui bahwa ternyata ada pengaruh antara penggunaan permainan scrabble terhadap kemampuan membaca siswa disleksia. $^{20}$

Penelitian selanjutnya dilakukan oleh Rifa Hidayah dengan menganalisis kemampuan membaca siswa disleksia. ${ }^{21}$ Hasil penelitiannya menunjukkan bahwa anak disleksia memiliki kemampuan membaca dan menulis yang rendah, adapun faktor-faktor yang mempengaruhinya adalah adanya disfungsi pada sistem syaraf, keterlambatan perkembangan karena gizi, terkendala memori yang pendek, fasilitas belajar yang kurang, belum matang secara fisik maupun sosial emosional dan dukungan dari keluarga yang kurang. Agar anak disleksia dapat terbantu dalam mengatasi kesulitan belajar yang dialami maka dalam penelitian tersebut menyarankan agar anak disleksia diberi perlakuan khusus, salah satunya adalah penyediaan guru pembimbing khusus dan metode pembelajaran yang sesuai adalah menggunakan alat bantu visual. Penelitian selanjutnya dilakukan dengan melakukan penggunaan metode multisensory dalam meningkatkan kemampuan membaca. Penelitian tersebut ternyata efektif dalam meningkatkan pengenalan kata, serta meningkatkan jumlah kata yang dapat dibaca tiap menit. Beberapa penelitian di atas menyimpulkan bahwa penggunaan media visual terbukti efektif dalam meningkatkan kemampuan membaca. Maka dari itu dalam penelitian ini akan mengkaji penggunaan media visual terutama media gambar untuk meningkatkan kemampuan membaca.

Terdapat penelitian terdahulu yang mengkaji tentang penggunaan media gambar dalam meningkatkan kemampuan membaca. Salah satu jenis media gambar yang sering dipakai sebagai media pembelajaran membaca adalah media gambar berseri. Terdapat beberapa hasil penelitian yang menunjukkan efektivitas media

\footnotetext{
${ }^{19}$ R. S Umar and others, Menggunakan Animasi Di Dalam Instruksi Khas Untuk Kanak-Kanak Disleksia, Jurnal Teknologi Pendidikan Malaysia, 2011, hlm. 27-38.

${ }^{20} \mathrm{~V}$. Saadah and N. Hidayah, Pengaruh Permainan Scrabble Terhadap Peningkatan Kemampuan Membaca Anak Disleksia, Empathy, 2013, hlm. 39-52.

${ }^{21}$ Rifa Hidayah, Kemampuan Baca-Tulis Siswa Disleksia, LiNGUA: Jurnal Ilmu Bahasa Dan Sastra, 4.1 (2011) < https://doi.org/10.18860/ling.v4i1.586>.
} 
tersebut dalam meningkatkan kemampuan membaca siswa. Penelitian pertama dilakukan oleh Dian Yusnita pada tahun 2016, dalam penelitian tersebut telah dinyatakan bahwa kemampuan membaca siswa sesudah penggunaan media gambar berseri terjadi peningkatan. ${ }^{22}$ Peningkatan tersebut terjadi pada aspek literal dan aspek interpretatif. Penelitian kedua dilakukan oleh Prabawati pada tahun 2013 yang menghasilkan kesimpulan bahwa model CIRC berbantuan media gambar berseri berpengaruh terhadap kemampuan membaca siswa kelas V Sekolah Dasar. ${ }^{23}$ Penelitian ketiga dilakukan oleh Ridik Pangestu pada tahun 2019 yang menyatakan bahwa penggunaan media gambar berseri dapat meningkatkan motivasi membaca siswa kelas II SD. ${ }^{24}$ Penelitian kelima dilakukan oleh Suhaimi pada tahun 2013, melalui kajian tersebut peneliti mengambil simpulan bahwa kemampuan membaca pada anak tuna grahita ringan dapat ditingkatkan melalui penggunaan media gambar berseri. ${ }^{25}$

Beberapa penelitian di atas mengkaji tentang penggunaan media gambar berseri untuk mengatasi kesulitan membaca pada siswa yang berkategori normal, sedangkan pada penelitian yang akan dilakukan ini mengkaji tentang penggunaan media gambar berseri untuk anak siswa disleksia. Hanya penelitian terakhir saja yang mengkaji tentang penggunaan media gambar berseri untuk meningkatkan kemampuan membaca untuk anak berkebutuhan khusus. Perbedaan penelitian tersebut dengan penelitian yang akan dilakukan terletak pada subjek penelitiannya. Pada penelitian yang telah dilakukan subjek penelitiannya adalah anak tuna grahita ringan, sedangkan penelitian yang akan dilakukan subjek penelitiannya siswa disleksia.

Penelitian ini bertujuan untuk menganalisis apakah media gambar berseri dapat digunakan untuk meningkatkan kemampuan membaca siswa disleksia. Alasan penggunaan media gambar berseri adalah siswa disleksia memiliki karakteristik yang berbeda dengan siswa normal pada umumnya yaitu memiliki ingatan yang pendek dan

${ }^{22}$ Dian Yusnita, Efektivitas Penggunaan Media Gambar Berseri Terhadap Peningkatan Kemampuan Membaca Pemahaman, Universitas Pendidikan Indonesia, 2016, <http://repository.upi.edu/id/eprint/27658>

${ }^{23}$ I Gst Ayu Dewi Chandra Ayu Prabawati, Ni Nym Garminah, and I Wyn Widiana, Pengaruh Model CIRC Berbantuan Media Gambar Berseri Terhadap Kemampuan Membaca Pemahaman Pada Siswa Kelas $V$ SD Gugus IV Kecamatan Rendang, E-Journal MIMBAR PGSD Universitas Pendidikan Ganesha, 2013, $<$ https://ejournal.undiksha.ac.id/index.php/JJPGSD/article/view/833/706>

${ }^{24}$ Ridik Pangestu, Increasing Reading Interest Using Serial Pictures Media to 2 Nd Grade of Student, Jurnal Pendidikan $\quad$ Guru $\quad$ Sekolah $\quad$ Dasar, 2019 , $<$ http://journal.student.uny.ac.id/ojs/index.php/pgsd/article/view/14629/14201>

${ }^{25}$ Suhaimi, Meningkatkan Kemampuan Membaca Pemahaman Melalui Gambar Berseri Bagi Anak Tunagrahita Ringan Kelas D III YAPEM Tarusan Pesisir Selatan, Jurnal Ilmiah Pendidikan Khusus, 1.1, 2013, 470-77<http://ejournal.unp.ac.id/index.php/jupekhu/article/viewFile/974/826> 
kesulitan dalam mengenali kata sehingga membutuhkan alat bantu sebagai media pembelajarannya. Melalui kajian ini diharapkan dapat menemukan media pembelajaran yang tepat untuk meningkatkan kemampuan membaca siswa disleksia. Masalah utama dalam penelitian ini adalah apakah media gambar berseri dapat digunakan untuk meningkatkan kemampuan membaca siswa disleksia di SDN Repok Puyung.

\section{B. METODE PENELITIAN}

Penelitian ini dirancang dalam bentuk penelitian kualitatif. Peneliti dalam hal ini bertindak sebagai observer. Peneliti mengamati aktivitas eksperimen yang dilakukan oleh guru di dalam kelas. Sumber data dalam penelitian ini berupa sumber primer dan sumber skunder. Sumber primer diperoleh melalui test, observasi dan wawancara, sedangkan sumber sekunder berasal dari artikel ilmiah, buku dan dokumen lain yang relevan. Penelitian dilakukan selama satu bulan di SDN Repok Puyung kabupaten Lombok Tengah. Pengumpulan data dilakukan melalui test, observasi dan wawancara. Instrument yang digunakan dalam pengumpulan data adalah test membaca, pedoman observasi dan pedoman wawancara. Data disajikan dalam bentuk angka dan deskripsi kata-kata, karena dalam penelitian ini selain menghasilkan data kuantitatif juga menghasilkan data kualitatif. Analisis data dilakukan bersamaan pada waktu pengumpulan data. Subjek dalam penelitian ini adalah siswa dengan kesulitan belajar tipe disleksia di SDN Repok Puyung yang berjumlah lima siswa. Penelitian ini juga melibatkan guru sebagai informan. Pengecekan hasil temuan dilakukan dengan diskusi teman sejawat dan memperpanjang observasi.

\section{HASIL DAN PEMBAHASAN}

Berdasarkan hasil observasi awal siswa disleksia di SDN Repok Puyung mengalami kesulitan akademik dasar yang meliputi aktivitas membaca dan menulis. Kesulitan akademik siswa tersebut diperparah dengan adanya motivasi belajar yang rendah. Implikasinya siswa disleksia semakin tertinggal dengan teman sekelasnya. Bertolak dari permasalahan tersebut guru kelas melakukan berbagai upaya untuk meningkatkan kemampuan akademik siswa disleksia. Salah satu kemampuan akademik yang akan ditingkatkan oleh guru saat ini adalah kemampuan membaca. Berdasarkan kajian beberapa teori dapat diketahui bahwa anak disleksia mempunyai daya ingat yang rendah dan kesulitan dalam mengenali kata. Melalui penggunaan 
media gambar berseri diharapkan dapat membantu anak disleksia dalam mengingat kata demi kata melalui gambar.

Siswa disleksia di SDN Repok Puyung berjumlah lima siswa. Pada saat pembelajaran kelima siswa tersebut diberi perlakuan khusus, walaupun pembelajaran masih dilakukan dalam satu kelas yang sama dengan kelas reguler. Kelima siswa tersebut dikelompokkan tersendiri kemudian diberi tugas yang berbeda dengan siswa normal di kelasnya. Pelaksanaan pembelajaran diawali dengan penyampaian materi pelajaran yang akan dipelajari pada hari itu. Guru kemudian memperkenalkan metode dan media yang akan digunakan pada proses pembelajaran tersebut. Pada hari itu metode yang digunakan adalah metode diskusi interaktif. Penggunaan diskusi interaktif dirasa cukup efektif dalam merangsang pengetahuan dan daya ingat anak disleksia. Media yang digunakan pada hari itu adalah media visual yang berupa gambar. Media gambar yang digunakan oleh guru ada dua macam yaitu gambar aktivitas rutin seharihari dan gambar metamorfosis sempurna kupu-kupu. Penggunaan kedua media tersebut disesuaikan dengan tema yang sedang dipelajari siswa.

Sebelum memulai aktivitas pembelajaran guru memberikan pretest. Hal ini dilakukan untuk mengetahui kemampuan awal membaca siswa sebelum diberi treatment. Pada akhir pembelajaran dilakukan evaluasi dengan melakukan test membaca (postest). Hasil test membaca tersebut kemudian dianalisis untuk mengetahui apakah terjadi peningkatan kemampuan membaca atau tidak. Gambar pertama yang disajikan kepada anak disleksia adalah metamorphosis sempurna kupu-kupu dan gambar kedua adalah aktivitas rutin sehari-hari. Melalui kedua gambar tersebut anak disleksia dilatih untuk merangkai urutan metamorphosis dan aktivitas yang biasa dilakukan sehari-hari. Hal ini dilakukan sebagai salah satu cara dalam meningkatkan daya ingat siswa, mengingat daya ingat anak disleksia relatif pendek. Melalui cara ini diharapkan anak disleksia terbantu dalam mengingat kegiatan yang sehari-hari dilakukan dan mampu menghubungkan apa yang dipelajari dengan dunia nyata. Berikut ini gambar metamorphosis sempurna yang digunakan pada pertemuan pertama: 


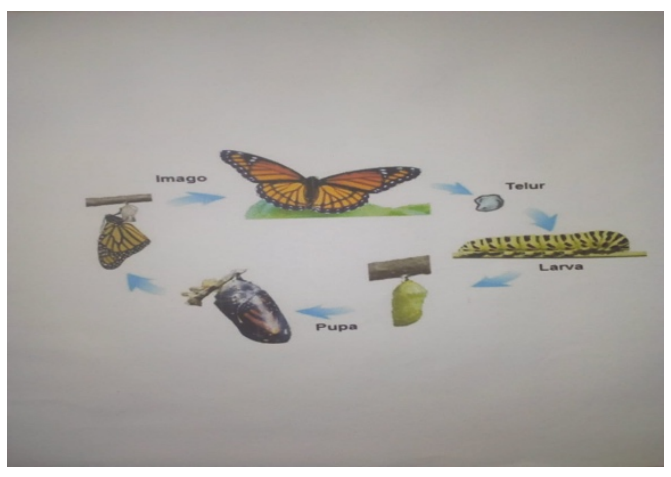

Gambar 1. Metamorphosis sempurna kupu-kupu

Langkah pembelajaran diawali dengan penjelasan guru terkait dengan metamorphosis kupu-kupu. Guru menunjukkan gambar metamorphosis dan menjelaskan urutan daur hidup kupu-kupu. Setelah terjadi beragam diskusi dan interaksi kemudian guru memberikan treatment pada anak disleksia. Gambar metamorphosis kupu-kupu dipotong-potong kemudian diacak. Satu persatu anak disleksia diberi potongan gambar. Tidak lupa guru juga menyediakan lem agar memudahkan dalam menempel gambar. Setelah semua siswa mendapat gambar yang sama, maka langkah selanjutnya adalah memerintahkan anak disleksia untuk menyusun gambar seperti yang telah dijelaskan sebelumnya. Guru mengamati aktivitas belajar siswanya sekaligus melihat kemampuan mengingat siswanya. Setelah semua siswa selesai mengerjakan kemudian guru menunjuk beberapa anak disleksia untuk menunjukkan hasil pekerjaanya.

Berdasarkan hasil penelitian dapat diketahui bahwa Subjek pertama sangat kesulitan dalam mengingat penjelasan guru. Berdasarkan hasil wawancara dengan guru kelasnya subjek pertama memang mengalami disleksia berat, sehingga sangat kesulitan dalam belajar maupun menerima perintah. Hasil lebih baik ditunjukkan pada subjek kedua yang telah mampu menyusun dengan benar gambar metomorfosis kupu-kupu walaupun masih belum tepat dalam meletakkan tanda panah. Subjek kedua telah mampu menyusun gambar sesuai dengan intsruksi guru. Kesalahan pada tanda arah panah terjadi karena subjek kedua kesulitan dalam menentukan arah gambar. Hal serupa juga terjadi pada subjek ketiga. Kesalahan subjek ketiga terletak pada arah gambar kupu-kupu dewasa, larva dan pupa. Dari sini terlihat jika subjek ketiga masih kesulitan dalam mengurutkan gambar sesuai dengan arah yang benar. Subjek keempat juga mengalami hal yang tidak jauh berbeda dengan subjek sebelumnya, yakni mengalami kesulitan dalam menentukan arah gambar. Hasil pekerjaan siswa yang 
benar hanya ditunjukkan oleh subjek kelima yang dapat mengingat dengan betul arah dan urutan gambar sesuai dengan penjelasan guru.

Berdasarkan hasil pekerjaan siswa pada pertemuan pertama dapat terlihat bahwa anak disleksia belum sepenuhnya mampu mengingat penjelasan yang diberikan oleh guru. Hal ini dapat terlihat dari adanya kesalahan dalam meletakkan arah gambar meskipun urutan gambar telah sesuai. Melihat hal tersebut kemudian guru membimbing anak disleksia untuk menyusun gambar yang benar. Setelah gambar dipastikan dapat telah urut sebagaimana penjelasan guru maka anak disleksia diperintahkan untuk membaca keterangan pada tiap gambar.

Pada pertemuan pertama yang dilakukan anak disleksia hanya mengurutkan gambar dan membaca keterangan yang ada pada tiap gambar. Pada pertemuan kedua selain menyusun gambar berseri anak disleksia juga dilatih untuk menulis. Adapun gambar yang dipakai adalah aktivitas sehari-hari. Gambar ini digunakan untuk mempermudah anak disleksia untuk mengingat apa yang biasa mereka lakukan. Hal ini merupakan salah satu model pembelajaran kontekstual sehingga anak dapat menghubungkan kegiatan pembelajaran dengan aktivitas sehari-hari. Anak disleksia kemudian diberi tugas untuk memberi keterangan gambar sendiri sesuai dengan yang mereka pahami. Melalui keterangan gambar yang dibuat sendiri diharapkan anak disleksia dapat mengingat apa yang telah mereka lakukan, sehingga memudahkan dalam aktivitas membaca. Hal ini dikarenakan membaca tulisan sendiri lebih mudah jika dibandingkan dengan membaca tulisan orang lain.

Teknik pembelajaran pada pertemuan kedua ini sedikit berbeda dengan pertemuan pertama. Jika pada pertemuan pertama gambar telah dipotong-potong untuk memudahkan penempelan maka dalam treatment kedua tidak demikian. Gambar aktivitas sehari-hari disajikan pada satu lembar yang utuh. Anak disleksia cukup memberi tanda urutan kegiatan dari yang paling dahulu dilakukan. Gambar yang disajikan urutan nomornya masih acak, tugas siswa adalah menyusun gambar sesuai dengan nomor gambar yang tepat. Jika pada treatment pertama siswa masih dapat melakukan trial and error dalam menyusun gambar maka dalam treatment kedua siswa dilatih untuk berpikir sedikit abstrak. Setelah anak disleksia dapat mengurutkan dengan benar langkah selanjutnya adalah menuliskan nama kegiatan tersebut pada masing-masing nomor yang telah ditandai. Tujuan menuliskan nama kegiatan seharihari tidak hanya sekedar latihan menulis tetapi sebagai treatment agar anak disleksia 
dapat mengingat betul kata demi kata yang telah dituliskan sendiri. Hal ini dikarenakan selain membaca tulisan sendiri itu lebih mudah dipahami tetapi juga dapat digunakan sebagai jembatan pengingat. Subjek pertama dapat menulis keterangan gambar dengan benar walaupun pada awalnya masih terdapat coretan dalam menulis nama sendiri. Hal ini menunjukkan bahwa ingatan siswa belum begitu baik. Perlu dilakukan terapi secara berkelanjutan untuk perbaikan ingatan. Subjek pertama juga belum dapat membedakan penggunaan huruf kecil dan huruf kapital dalam sebuah tulisan. Selain itu penggunaan spasi juga belum tepat. Hal ini dapat disimpulkan bahwa meskipun secara redaksi benar tulisan subjek pertama untuk tingkat keterbacaan tulisannya masih perlu diperbaiki.

Hasil yang tidak jauh berbeda juga ditunjukkan oleh subjek kedua. Masih terdapat coretan dan tidak ada spasi dalam menulis keterangan gambar. Tingkat keterbacaan tulisan siswa pada subjek kedua juga masih rendah. Hal ini dapat terlihat dari bentuk huruf yang kurang teratur. Namun demikian jika dibandingkan pada treatment pertama subjek kedua telah mengalami perbaikan ingatan yaitu dapat mengurutkan gambar dengan tepat.

Hasil yang lebih bagus diperlihatkan oleh subjek ketiga. Subjek ketiga dapat menulis dengan baik mulai dari bentuk huruf hingga penggunaan spasi. Terdapat sedikit kesalahan penulisan dari subjek ketiga namun secara umum kemampuan menulis subjek ketiga mengalami perbaikan. Subjek keempat dalam menulis keterangan gambar masih terdapat banyak tulisan antara lain: kelengkapan huruf, penggunaan huruf kapital dan sering salah dalam menulis. Akibat sering salah dalam menulis kata dapat terlihat dari adanya coretan. Namun demikian penggunaan spasi oleh subjek keempat sudah tepat.

Hasil penelitian dari subjek kelima dapat menulis dengan tepat keterangan gambar. Tingkat keterbacaan tulisan juga telah membaik. Hal ini dapat terlihat dari konsistensi subjek kelima dalam penggunaan huruf kapital unuk menulis keterangan gambar. Namun demikian masih ditemui beberapa coretan dalam pekerjaan subjek kelima. Hal ini menunjukkan bahwa subjek kelima masih mengalami kesulitan dalam menulis.

Meningkatkan kemampuan menulis anak disleksia bukanlah pekerjaan mudah. Hal inilah yang merupakan tantangan dan hambatan dalam melakukan pendidikan 
inklusi. ${ }^{26}$ Namun demikian jika dibandingkan dengan pertemuan pertama pada pertemuan kedua sejumlah anak disleksia mengalami perbaikan ingatan. Indikatornya adalah siswa mampu menyusun urutan gambar dengan urut dan tepat. Hal ini menunjukkan bahwa anak disleksia telah mampu mengingat langkah-langkah rutinitas yang dilakukan sehari hari. Langkah selanjutnya setelah menyusun gambar adalah memberikan label. Siswa diperintahkan untuk menuliskan nama kegiatan yang ada pada masing-masing gambar. Berdasarkan analisis terhadap hasil pekerjaan siswa di atas dapat diketahui bahwa kemampuan menulis anak disleksia belum begitu bagus. Hal ini dapat terlihat dari tingkat keterbacaan tulisan yang rendah. Rendahnya keterbacaan tulisan dapat terlihat dari tidak adanya spasi antar kata, huruf dalam tiap kata belum lengkap, tidak dapat membedakan huruf yang bentuknya mirip dan sering terbalik hurufnya.

Aktivitas pembelajaran yang dilakukan setelah treatment gambar kedua adalah test kemampuan membaca. Setelah melakukan diskusi siswa diminta untuk merangkum hasil diskusinya, kemudian membacakannya di depan kelas. Indikator yang digunakan untuk mengetahui kemampuan membaca siswa adalah: 1) Mampu merangkai huruf dalam bentuk kata dengan benar, 2) Mampu merangkai kata dalam bentuk kalimat dengan benar, 3) Mampu melafalkan bacaan dengan intonasi yang baik dan benar, 4) Mampu menjawab pertanyaan berdasarkan gambar yang disajikan, 5) Mampu mendeskripsikan rangkaian gambar dengan benar, 6) Mampu membuat simpulan dengan benar dari gambar berseri, dan 7) Mampu menghubungkan gambar berseri dengan pengalaman hidup sehari-hari.

Hasil test membaca siswa berdasarkan indikator di atas dapat disajikan pada diagram berikut ini:

${ }^{26}$ Meng Deng and Kim Fong Poon-McBrayer, Reforms and Challenges in the Era of Inclusive Education: The Case of China, British Journal of Special Education, 39.3, 2012, page. 117-22 $<$ https://doi.org/10.1111/j.1467-8578.2012.00551.x> 


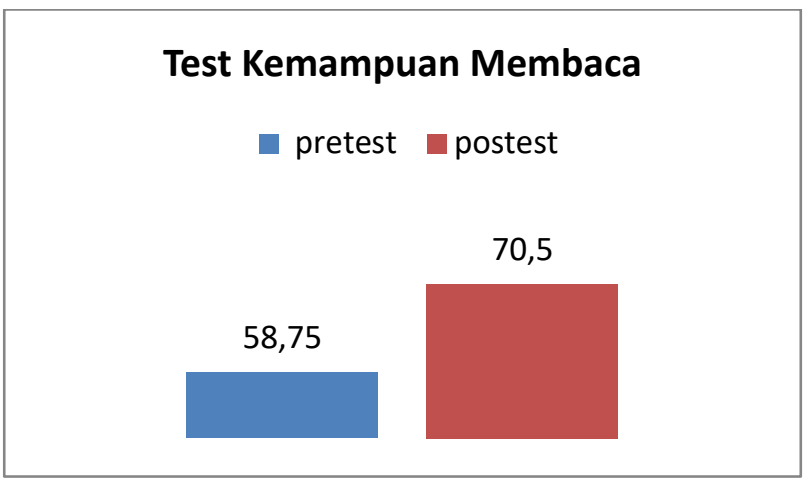

Gambar 2. Test Kemampuan Membaca

Berdasarkan gambar di atas dapat diketahui bahwa rata-rata kemampuan membaca siswa disleksia sebelum diberi perlakuan (pretest) adalah 58.75. Nilai ratarata kemampuan membaca setelah diberi perlakuan (posttest) adalah 70.5. Hal ini menunjukkan bahwa terjadi peningkatan kemampuan membaca setelah diberi perlakuan. Kemampuan membaca setelah treatment terjadi peningkatan hal ini dapat terlihat dengan semakin lancarnya mereka membaca, sedikit mengeja, dan jumlah kata yang dibaca tiap menit telah meningkat.

Hasil penelitian di atas sesuai dengan beberapa hasil penelitian terdahulu yang menyatakan bahwa media gambar berseri dapat meningkatkan kemampuan membaca siswa tuna grahita ringan. Hal ini bermakna bahwa media gambar berseri tidak hanya dapat diterapkan pada anak normal saja, tetapi juga dapat diterapkan pada anak berkebutuhan khusus, salah satunya adalah penderita disleksia. Hal ini menunjukkan bahwa media gambar berseri efektif sebagai sarana dalam membantu ingatan anak disleksia yang relatif pendek. Penelitian di atas menunjukkan bahwa penggunaan media visual dapat digunakan untuk meningkatkan kemampuan membaca anak disleksia.

Hasil analisis terhadap kemampuan membaca siswa disleksia pada aspek kemampuan merangkai huruf dalam bentuk kata terjadi peningkatan. Hal ini dapat terlihat siswa mampu merangkai huruf dengan benar ketika diberi tugas menyebutkan rangkaian kata dalam gambar berseri. Kemampuan merangkai kata dalam bentuk kalimat juga terlihat ada peningkatan. Hal ini dapat terlihat ketika siswa diberi tugas untuk membaca tulisannya di depan kelas kata demi kata yang dibacakan telah runtut. Kemampuan membaca pada aspek penggunaan intonasi yang tepat dapat terlihat ketika siswa diberi tugas untuk membacakan hasil simpulan di depan kelas. Siswa terlihat 
telah mampu membaca dengan tepat sesuai dengan penggunaan tanda baca yang seharusnya.

Siswa juga terlihat sangat baik ketika diperintahkan mendeskripsikan gambar serta menghubungkan rangkaian gambar tersebut dengan kehidupan sehari-hari. Hanya saja jika diperintahkan untuk memberikan simpulan berdasarkan gambar tersebut masih ada siswa yang kebinggungan. Siswa tersebut menoleh ke kanan dan ke kiri yang menandakan belum memahami apa yang diperintahkan guru. Kemampuan membuat simpulan merupakan salah satu keterampilan berpikir tingkat tinggi. ${ }^{27}$ Melalui media gambar tersebut siswa dilatih untuk berpikir kritis serta dapat menghubungkan gambar yang dipelajari dengan kehidupan sehari-hari sehingga tuntutan pembelajaran kontekstual dapat tercapai.

Berdasarkan pengamatan terhadap aktivitas belajar di kelas, penggunaan media gambar berseri dapat meningkatkan aktivitas belajar siswa. Aktivitas belajar merupakan rangkaian kegiatan yang melibatkan keaktifan siswa dalam pembelajaran, seperti bertanya, berpikir, membaca serta kegiatan lainnya yang bermanfaat untuk meningkatkan prestasi belajar. ${ }^{28}$ Aktivitas belajar yang dilakukan selama pembelajaran selain yang telah disebutkan di atas adalah kegiatan tutor sebaya. Siswa terlihat antusias dalam kegiatan pembelajaran. Beberapa siswa yang memiliki kemampuan lebih mau membantu teman lain yang memiliki kekurangan dalam hal akademik.

Penggunaan media gambar tersebut merangsang aktivitas belajar menjadi lebih aktif. Hal ini menunjukkan bahwa penggunaan media yang tepat dapat meningkatkan motivasi belajar juga dapat meningkatkan keaktifan belajar siswa. Siswa terlihat lebih bersemangat untuk menunggu giliran membaca. Terlebih lagi dengan pujian yang dilakukan oleh guru membuat siswa semakin senang. Membaca tidak hanya kewajiban bagi seorang siswa tetapi juga merupakan kebutuhan. Melalui membaca samudera pengetahuan yang luas dapat dijelajahi. ${ }^{29}$ Pemberian apresiasi oleh guru walaupun hanya dengan memberikan tanda jempol membuat motivasi belajar siswa meningkat.

27 Arif Widodo, Dyah Indraswati, Radiusman Radiusman, and others, Analisis Konten HOTS Dalam Buku Siswa Kelas V Tema 6 “ Panas Dan Perpindahannya” Kurikulum 2013, Madrasah: Jurnal Pendidikan dan Pembelajaran Dasar, 2019, hlm. 1-13<https://doi.org/http://dx.doi.org/10.18860/mad.v12i1.7744>

${ }^{28}$ Sari Asparina, Mahwar Qurbaniah, and Nuri Dewi Muldayanti, Analisis Aktivitas Belajar Siswa Berdasarkan Waktu Pembelajaran Pada Materi Struktur Dan Fungsi Sel Di Kelas XI IPA Mas Al-Mustaqim Sungai Raya, Pena Kreatif: Jurnal Pendidikan, 2019, hlm. 89-101 $<$ http://openjurnal.unmuhpnk.ac.id/index.php/JPK/article/viewFile/1782/1250>

${ }^{29}$ Arif Widodo, Dyah Indraswasti, Muhammad Erfan, and others, Profil Minat Baca Mahasiswa Baru PGSD Universitas Mataram, Premiere Educandum : Jurnal Pendidikan Dasar Dan Pembelajaran, 2020, hlm. 34 $<$ https://doi.org/10.25273/pe.v10i1.5968> 
Pemberian tanda jempol menandakan bahwa kemampuan membaca siswa telah baik. Hal ini sesuai dengan pernyataan dalam penelitian sebelumnya bahwa guru berperan sangat penting sebagai motivator dalam pembelajaran. ${ }^{30}$

Meskipun dalam aspek membaca anak disleksia telah mengalami perbaikan akan tetapi dalam kegiatan menulis masih perlu dilakukan tindakan lebih lanjut. Hal ini terlihat dari tulisan anak disleksia yang masih kurang tepat dalam menulis kata. Beberapa siswa masih sulit membedakan dalam menulis hurus "a" dengan " $d$ " sehingga kedua huruf tersebut tampak sama. Penggunaan huruf besar dan kecil juga perlu diperbaiki. Hal ini merupakan tantangan berat bagi guru agar meningkatkan terus kompetensinya dalam mengajar. Beberapa penelitian terdahulu telah menyatakan bahwa kompetensi guru dalam memberikan layanan belajar membaca terhadap anak disleksia harus ditingkatkan. ${ }^{31}$ Guru perlu meningkatkan kompetensi dalam memberikan layanan belajar, karena anak berkebutuhan khusus memerlukan pertolongan agar dapat keluar dari masalah yang dihadapinya.

\section{SIMPULAN}

Berdasarkan hasil penelitian dapat disimpulkan beberapa hal yang merupakan jawaban dari rumusan masalah, diantaranya: 1) penggunaan media gambar berseri dapat meningkatkan kemampuan membaca siswa disleksia. 2) media gambar berseri berfungsi sebagai jembatan pengingat bagi anak disleksia sehingga dapat membantu meningkatkan kemampuan membaca. 3) penggunaan media gambar dapat meningkatkan motivasi membaca siswa. Maka dari itu dalam menangani anak berkebutuhan khusus tipe disleksia hendaknya para guru menggunakan media yang dapat membantu daya ingat siswa. Mengingat siswa disleksia memiliki daya ingat yang rendah sehingga kesulitan dalam membaca.

30 Jahara, Anandita eka Setiadi, and Arif Didik Kurniawan, Analisis Peran Guru Dalam Menumbuhkan Motivasi Belajar Siswa Pada Pelajaran IPA Di MTS Negeri 1 Pontianak, Pena Kreatif: Jurnal Pendidikan, 2019, hlm.18-31 <http://openjurnal.unmuhpnk.ac.id/index.php/JPK/article/viewFile/1777/1167>

${ }^{31}$ Irdamurni and others, Meningkatkan Kemampuan Guru Pada Pembelajaran Membaca Anak Disleksia, Jurnal Pendidikan Kebutuhan Khusus, 2018, hlm. 29-32 


\section{DAFTAR PUSTAKA}

A'la, Miftachul, Penguatan Karakter Toleransi Melalui Permainan Tradisional Dalam Pembelajaran PJOK di Sekolah Dasar, MAGISTRA: Media Pengembangan Ilmu Pendidikan Dasar Dan KeIslaman, 2019

Anjarsari, Anggun Dyah, Penyelenggaraan Pendidikan Inklusi Pada Jenjang SD, SMP, dan SMA Di Kabupaten Sidoarjo, JPI (Jurnal Pendidikan Inklusi, 2018 $<$ https://doi.org/10.26740/inklusi.v1n2.

Asparina, Sari, Mahwar Qurbaniah, and Nuri Dewi Muldayanti, Analisis Aktivitas Belajar Siswa Berdasarkan Waktu Pembelajaran Pada Materi Struktur Dan Fungsi Sel Di Kelas XI IPA Mas Al-Mustaqim Sungai Raya, Pena Kreatif: Jurnal Pendidikan, 2019, <http://openjurnal.unmuhpnk.ac.id/index.php/JPK/article/viewFile/1782/1250>

Deng, Meng, and Kim Fong Poon-McBrayer, Reforms and Challenges in the Era of Inclusive Education: The Case of China, British Journal of Special Education, 2012, <https://doi.org/10.1111/j.1467-8578.2012.00551.x>

Devaraj, Sheila, and Samsilah Roslan, Apa Itu Disleksia?: Panduan Untuk Ibu Bapa Guru \& Kaunselor, PTS Profesional, 2006

Haryati, Linda Feni, Radiusman, Iva Nurmawanti, Ashar Pajarungi Anar, and Arif Widodo, Optimalisasi Penggunaan Media Pada Anak Berkebutuhan Khusus Di MI NW Tanak Beak Narmada, Progres Pendidikan, 2020

Hidayah, Rifa, Kemampuan Baca-Tulis Siswa Disleksia, LiNGUA: Jurnal Ilmu Bahasa Dan Sastra, 2011, <https://doi.org/10.18860/ling.v4i1.586>

Irdamurni, Kasiyatil, Zulmiyetri, and Johandri Taufan, Meningkatkan Kemampuan Guru Pada Pembelajaran Membaca Anak Disleksia, Jurnal Pendidikan Kebutuhan Khusus, 2018

Jahara, Anandita eka Setiadi, and Arif Didik Kurniawan, Analisis Peran Guru Dalam Menumbuhkan Motivasi Belajar Siswa Pada Pelajaran IPA Di MTS Negeri 1 Pontianak, Pena Kreatif: Jurnal Pendidikan, 2019, <http://open jurnal. unmuhpnk. ac. id/index.php/JPK/article/viewFile/1777/1167>

Kawuryan, Fajar, and Trubus Raharjo, Pengaruh Stimulasi Visual Untuk Meningkatkan Kemampuan Membaca Pada Anak Disleksia, 10 Jurnal Psikologi Pitutur, 2012

Lalu Satya, Purwanata, and Rianto Edy, Penerapan Media Video Berbasis IT Terhadap Kemampuan Membaca Kalimat Sederhana Anak Tunagrahita Ringan Kelas III', Pendidikan Khusus, 2016, <https://jurnalmahasiswa.unesa.ac.id/index.php/jurnalpendidikan-khusus/article/view/30061/27561>

Majzub, Rohaty Mohd, and Shafie Mohd Nor, Simptom Disleksia Kanak-Kanak Prasekolah, 
Jurnal Pendidikan Malaysia, 2005

Pangestu, Ridik, Increasing Reading Interest Using Serial Pictures Media to $2 \mathrm{Nd}$ Grade of Student, Jurnal Pendidikan Guru Sekolah Dasar, 2019, <http://journal.student.uny.ac.id/ojs/index.php/pgsd/article/view/14629/14201>

Peraturan Menteri Pendidikan Nasional (Permendiknas) Nomor 70 Tahun 2009 Tentang Pendidikan Inklusif Bagi Peserta Didik Yang Memiliki Kelainan Dan Memiliki Potensi Kecerdasan Dan/Atau Bakat Istimewa (Republik Indonesia, 2009) <https://kelembagaan.ristekdikti.go.id/wp-content/uploads/2016/11/Permen-No.-702009-tentang-pendidiian-inklusif-memiliki-kelainan-kecerdasan.pdf>

Prabawati, I Gst Ayu Dewi Chandra Ayu, Ni Nym Garminah, and I Wyn Widiana, Pengaruh Model CIRC Berbantuan Media Gambar Berseri Terhadap Kemampuan Membaca Pemahaman Pada Siswa Kelas V SD Gugus IV Kecamatan Rendang, E-Journal MIMBAR PGSD Universitas Pendidikan Ganesha, 2013, https://ejournal.undiksha.ac.id/index.php/JJPGSD/article/view/833/706

Rofiah, Nurul Hidayati, Proses Identifikasi: Mengenal Anak Kesulitan Belajar Tipe Disleksia Bagi Guru Sekolah Dasar Inklusi, INKLUSI, 2015, https://doi.org/10.14421/ijds.020110

Saadah, V., and N. Hidayah, Pengaruh Permainan Scrabble Terhadap Peningkatan Kemampuan Membaca Anak Disleksia, Empathy, 2013

Slater, Eileen, The Identification of Gifted Children in Australia: The Importance of Policy, TalentEd, 2018, <https: // www. researchgate. net/profile / Eileen_Slater / publication / 322419883>

Suhaimi, Meningkatkan Kemampuan Membaca Pemahaman Melalui Gambar Berseri Bagi Anak Tunagrahita Ringan Kelas D III YAPEM Tarusan Pesisir Selatan, Jurnal Ilmiah Pendidikan Khusus, 2013, <http : // ejournal. Unp . ac . id / index. Php / jupekhu / article /viewFile/974/826>

Sulthon, Sulthon, Pendidikan Dasar Inklusif Di Kabupaten Pati: Harapan Dan Kenyataan, INKLUSI, 2019, https://doi.org/10.14421/ijds.060107

Umar, R. S, Fadilahwati Abdul Rahman, Fattawi Mokhtar, and Nor Aziah Alias, Menggunakan Animasi Di Dalam Instruksi Khas Untuk Kanak-Kanak Disleksia, Jurnal Teknologi Pendidikan Malaysia, 2005

Widodo, Arif, Penyimpangan Perilaku Sosial Ditinjau Dari Teori Kelekatan Bowlby (Studi Kasus Terhadap Anak Tenaga Kerja Wanita Di Lombok Barat), Entita: Jurnal Pendidikan Ilmu Pengetahuan Sosial Dan Ilmu-Ilmu Sosial, 2020

Widodo, Arif, Sa'dun Akbar, and Sujito Sujito, Analisis Nilai-Nilai Falsafah Jawa Dalam Buku Pitutur Luhur Budaya Jawa Karya Gunawan Sumodiningrat Sebagai Sumber Belajar 
Pada Pembelajaran IPS, Jurnal Penelitian Dan Pendidikan IPS (JPPI), 2017, http://ejournal.unikama.ac.id/index.php/JPPI/article/download/1887/1489/

Widodo, Arif, Linda Feni Haryati, Mohammad Archi Maulyda, Umar Umar, and Muhammad Erfan, 'Proses Identifikasi Peserta Didik Berkebutuhan Khusus Di MI NW Tanak Beak Kabupaten Lombok Barat.', Progres Pendidikan, 1.2 (2020), 63-71 http://prospek.unram.ac.id/index.php/PROSPEK/article/view/10/11

Widodo, Arif, Husniati Husniati, Dyah Indraswati, Aisa Nikmah Rahmatih, and Setiani Novitasari, Prestasi Belajar Mahasiswa PGSD Pada Mata Kuliah Pengantar Pendidikan Ditinjau Dari Segi Minat Baca, Jurnal Bidang Pendidikan Dasar, 2020, https://doi.org/https://doi.org/10.21067/jbpd.v4i1.3808

Widodo, Arif, Dyah Indraswasti, Muhammad Erfan, Mohammad Archi Maulyda, and Aisa Nikmah Rahmatih, Profil Minat Baca Mahasiswa Baru PGSD Universitas Mataram, Premiere Educandum: Jurnal Pendidikan Dasar Dan Pembelajaran, 2020, https://doi.org/10.25273/pe.v10i1.5968

Widodo, Arif, Dyah Indraswati, Radiusman Radiusman, Umar Umar, and Nursaptini Nursaptini, Analisis Konten HOTS Dalam Buku Siswa Kelas V Tema 6 "Panas Dan Perpindahannya "Kurikulum 2013', Madrasah: Jurnal Pendidikan Dan Pembelajaran Dasar, 2019, https://doi.org/http://dx.doi.org/10.18860/mad.v12i1.7744

Widodo, Arif, Dyah Indraswati, and Muhammad Sobri, Analisis Nilai-Nilai Kecakapan Abad 21 Dalam Buku Siswa SD/MI Kelas V Sub Tema 1 Manusia Dan Lingkungan, Tarbiyah: Jurnal Ilmiah Kependidikan, 2019, https://doi.org/10.18592/tarbiyah.v8i2.3231

Widodo, Arif, Dyah Indraswati, Deni Sutisna, Nursaptini Nursaptini, and Setiani Novitasari, Identifikasi Bakat Peserta Didik Berkebutuhan Khusus (PDBK) Di Madrasah Inklusi Kabupaten Lombok, JPI (Jurnal Pendidikan Inklusi), 2020, https: // doi. Org / 10.26740 / inklusi.v3n2.p102-116

Widyorini, Endang, and Julia Maria van Tiel, Disleksia: Deteksi, Diagnosis, Penanganan Di Sekolah Dan Di Rumah, 1st edn, Jakarta: Prenadamedia Group, 2017

Yusnita, Dian, Efektivitas Penggunaan Media Gambar Berseri Terhadap Peningkatan Kemampuan Membaca Pemahaman, Universitas Pendidikan Indonesia, 2016 <http://repository.upi.edu/id/eprint/27658> 